20. Бернам У. Суд присяжных заседателей. М.: МНИМП, 1995. 128с.; Нарутто С.В. Присяжные и арбитражные заседатели: теория и практика. М.: Проспект, 2008. 208c.; Соколовский В. Присяжные заседатели в Российской Федерации: история, назначение, функции: Дис. ... канд. юрид. наук. М., 2011. 187c.

21. Гуценко К.Ф., Головко Л.В., Филимонов Б.А. Уголовный процесс западных государств. М.: Зерцало-М, 2001. C. 267.

22. Насонов С.А. Модели пересмотра не вступивших в законную силу приговоров, постановленных на основании вердикта присяжных заседателей, в России и зарубежных странах // Lex russica. 2013. № 4. С. $382-$ 384.

23. Ковтун Н.Н. Апелляционное, кассационное и надзорное производство по уголовным делам в контексте соответствия международно-правовому стандарту // Международное уголовное право и международная юстиция. 2012. № 3. С. 4.

24. Дикарев И.С. Апология ревизии в уголовном процессе // Российская юстиция. 2012. № 11. С. $34-37$.

25. О соблюдении судами Российской Федерации процессуального законодательства при судебном разбирательстве уголовных дел: Постановление Пленума Верховного Суда РСФСР от 17 сентября 1975 г. № 5 (в ред. Постановления Пленума Верховного Суда РФ от 9 февраля 2012 г. № 3 (ред. от 19.12.2017г.) «О внесении изменений в некоторые постановления Пленума Верховного Суда Российской Федерации» // СПС «КонсультантПлюс» (Дата обращения: 21.07.2020 г.).

26. Курс уголовного процесса / Под ред. Л.В. Головко. М.: Стаут, 2017. С. 821.

27. Тришина Н.Т. Юридико-фактическая проверка приговора в апелляционном производстве: Автореф. дис. ... канд. юрид. наук. Саратов, 2012. С. 12; Рукавишникова (Плашевская) А.А. Апелляционный порядок проверки итоговых судебных решений по УПК РФ: полная или неполная апелляция // Вестник Томского гос. ун-та. Право. 2013. № 4(10). С. 108; Мазина Н.Н. Апелляционное производство в уголовном процессе России: коллизии предмета и пределов проверки // Актуальные проблемы экономики и права. 2013. № 4. С. 267.

28. п. 2 ст. 2 Протокола № 7 к Конвенции о защите прав человека и основных свобод. Подписан в г. Страсбурге 22.11.1984 г. // СПС «КонсультантПлюс» (Дата обращения: 17.06.2020 г.).

\title{
Илиджев А.А. \\ Содержание разбоя и его место в системе составных преступлений
}

Казанский юридический институт МВД России (Россия, Казань)

doi: 10.18411/trnio-11-2021-242

\section{Аннотация}

В статье исследуется уголовно-правовая сущность разбоя и иных смежных преступлений. В работе с учетом материалов судебной практики, а также некоторых подходов в уголовном праве к анализируемым составам проводится анализ, как разбоя, так и соответствующего квалифицированного вида грабежа. В ходе исследования определяется юридическая природа разбоя и определяется его место в системе составных преступлений.

Ключевые слова: грабеж, преступление, квалифицированный, насилие, жизнь, угроза, здоровье, нападение.

\section{Abstract}

The article examines the criminal-legal essence of robbery and other related crimes. In the work, taking into account the materials of judicial practice, as well as some approaches in criminal law, the analyzed compositions are analyzed, both robbery and the corresponding qualified type of robbery. In the course of the study, the legal nature of robbery is determined and its place in the system of compound crimes is determined.

Keywords: robbery, crime, skilled, violence, life, threat, health, assault.

В уголовно-правовой теории особо проблематичным оказалось отнесение к составным преступлениям разбоя и преступлений, включающих квалифицирующий признак применения насилия или угрозы его применения.

В уголовно-правовой литературе отмечается, что применение или угроза применения насилия, опасного для жизни или здоровья является обязательным признаком объективной 
стороны разбоя, и для квалификации такого преступления достаточно, чтобы насилие создавало опасность хотя бы для здоровья. Насилие должно считаться опасным для жизни, если способ его применения создавал реальную опасность наступления смерти, если даже он не причинил никакого реального вреда [5, с. 140-141]. Конструированию и правилам квалификации разбоя и преступлений, охватывающих применения насилия или угрозы его применения традиционно в отечественном уголовном праве уделялось пристальное внимание. Так, еще в период действия советского уголовного законодательства А.А. Пионтковский отмечал, «... Причиненное физическое насилие при разбойном нападении или грабеже с насилием не дает основания не дает основания квалифицировать все совершенное как совокупность преступлений - разбоя, грабежа с насилием и соответствующего преступления против личности, - а всегда составляет одно преступление - грабеж с насилием или разбой» [2, с. 360].

Н.Ф. Мурашов указывает, что основной состав разбоя даже теоретически нельзя расчленить на два состава: в УК РФ нет такого состава преступления, как нападение; нет и такого состава, как насилие, опасное для жизни или здоровья; отсутствует и состав угрозы применить насилие, опасное для жизни или здоровья; в УК РФ нет состава хищения чужого имущества; само хищение при разбое может быть как открытым, так и тайным; выводом является то, что разбой - это практически сложное односоставное преступление [3, с. 56].

Подход Н.Ф. Мурашова можно назвать поверхностным. Если же исходить из сущности разбоя, то нетрудно заметить, что простой разбой (ч. 1 ст. 162 УК РФ) предполагает два действия. Первое из них выражается в нападении в целях хищения чужого имущества, второе - в применении насилия, опасного для жизни или здоровья либо в угрозе применения такого насилия. И то, и другое признаются самостоятельными преступлениями. Первое действие, по общему правилу, проявляется в грабеже как открытом хищении чужого имущества (ч. 1 ст. 161 УК РФ), а в виде исключения может быть и кражей как тайном хищении (ч. 1 ст. 158).

В соответствии с абз. 2 п. 21 Постановления Пленума Верховного Суда РФ от 27 декабря 2002 г. № 29 под насилием, опасным для жизни или здоровья (ст. 162 УК РФ), следует понимать такое насилие, которое повлекло причинение тяжкого и средней тяжести вреда здоровью потерпевшего, а также причинение легкого вреда здоровью, вызвавшего кратковременное расстройство здоровья или незначительную стойкую утрату общей трудоспособности. При этом в абз. 4 того же пункта разъяснено, что применение насилия при разбойном нападении, в результате которого потерпевшему умышленно причинен легкий или средней тяжести вред здоровью, охватывается составом разбоя (ч. 1 ст. 162 УК РФ) $[1$, c. 5].

Отсюда последнее действие при простом разбое проявляется, прежде всего, в виде умышленного причинения легкого или средней тяжести вреда здоровью (ст. 112, 115 УК РФ). При угрозе же применения насилия, опасного для жизни или здоровья, такое действие заключается в угрозе убийством или причинением тяжкого вреда здоровью (ст. 119 УК РФ). Таким образом, составное преступление, хотя и не во всех случаях, очевидно. Конечно, его не будет, во-первых, при применении насилия, опасного для жизни или здоровья, которое не причинило вред здоровью потерпевшего, но в момент применения создавало реальную опасность для его жизни или здоровья [1, с. 5; 4]; во-вторых, при угрозе причинением легкого или средней тяжести вреда здоровью. Следовательно, по нашему мнению, разбой в отмеченном плане имеет смешанную уголовно-правовую природу.

В отношении преступлений, включающих квалифицирующий признак применения насилия или угрозы его применения, Н.Ф. Мурашов рассуждает аналогичным, как и применительно к разбою, образом. Он считает, что поскольку в УК РФ нет статей (следовательно, нет составов), предусматривающих ответственность за насилие, насилие, не опасное или опасное для жизни или здоровья, за угрозу применить названные виды насилия, постольку соответствующие преступления, имеющие указанные квалифицирующие 
признаки, являясь сложными единичными, составными не являются [3, с. 58-59]. Возражения этому, на наш взгляд, подобны высказанным в отношении разбоя.

Так, при грабеже, совершенном с применением насилия, не опасного для жизни или здоровья (п. «г» ч. 2 ст. 161 УК РФ), действия выражаются в открытом хищении чужого имущества и применении насилия, не опасного для жизни или здоровья. Оба они признаются самостоятельными преступлениями. Первое действие предусмотрено в ч. 1 ст. 161 УК РФ.

На основании абз. 1 п. 21 Постановления Пленума Верховного Суда РФ от 27 декабря 2002 г. № 29 под насилием, не опасным для жизни или здоровья, следует понимать побои или совершение иных насильственных действий, связанных с причинением потерпевшему физической боли либо с ограничением его свободы (связывание рук, применение наручников, оставление в закрытом помещении и др.) [1, с. 5]. Отсюда последнее действие, установленное в п. «Г» ч. 2 ст. 161 УК РФ, пусть и не во всех случаях, но предусмотрено в ст. 116. Следовательно, на наш взгляд, квалифицированный грабеж (п. «г» ч. 2 ст. 161 УК РФ), как и разбой, в рассмотренном плане имеет смешанную уголовно-правовую природу.

Похожие рассуждения приводят к выводу, что самостоятельно выделяемое в качестве вида сложного преступление, совершаемое посредством преступления-способа, - все-таки лишь разновидность составного преступления. Основное деяние в таком случае - тоже преступление.

1. Бюллетень Верховного Суда Российской Федерации. 2003. № 2.

2. Курс Советского уголовного права: Государственные преступления и преступления против социалистической собственности. В 6-ти томах: Часть особенная. Т. 4 / Меньшагин В.Д., Пионтковский А.А. М.: Наука, 1970. 432 с.

3. Мурашов Н.Ф. Совокупность преступлений по УК РФ: монография. М.: Юрлитинформ, 2018. 274 с.

4. П Постановление Пленума Верховного Суда РФ от 27 декабря 2002 г. № 29 «О судебной практике по делам о краже, грабеже и разбое».

5. Уголовное право. Особенная часть: учебник для бакалавров, 3-е изд-е, перераб. и доп. / под ред. А.А. Чучаева. М.: Проспект, 2018. 592 с.

\section{Кашурников С.Н., Качалина С.А. \\ Проблемы борьбы с коррупцией в судебных учреждениях и пути решения}

Финансовый университет при Правительстве Российской Федераџии

(Россия, Москва)

doi: 10.18411/trnio-11-2021-243

\section{Аннотация}

В данной статье мы разберем, какие существуют проблематики борьбы с коррупцией в судебных учреждениях, чем это обуславливается, какие существуют пути решения данной проблемы и возможно ли вообще искоренить коррупцию в данных учреждениях.

Ключевые слова: коррупция, судебные учреждения, взятка, борьба с коррупцией.

\section{Abstract}

In this article we will analyze what problems exist in the fight against corruption in judicial institutions, what causes it, what are the ways to solve this problem and whether it is possible to eradicate corruption in these institutions at all.

Keywords: corruption, judicial institutions, bribery, fight against corruption.

В предложенной авторами работе отражена специфика воздействия государственной власти России на противодействие коррупции. В настоящее время одной из основных государственных задач является эффективное противодействие коррупции в органах государственной власти, а именно в судебных учреждения. Существуют официальные данные, где показана такая статистика, что в коррупционные схемы вовлечены почти 90\% 